\title{
nature
}

\section{More good news from Moscow}

\section{Hoop-la arising from last week's summit meeting in Moscow should not elsewhere hide even more significant developments, of which the Soviet ambition to join GATT is the most striking.}

THE meeting between President Ronald Reagan of the United States and Mr Mikhail Gorbachev, the secretary-general of the Soviet Communist Party, may have filled the newspapers in the Soviet Union and the West last week, but what may be the most telling of a flood of announcements from Moscow has been given less attention than it deserves. By all accounts and, specifically, according to the Soviet Commission on Foreign Economic Relations, the Soviet Union intends to apply for membership of the General Agreement on Tariffs and Trade, termed GATT, two years from now and even has an ambition to make the rouble freely convertible into other currencies, perhaps as soon as the end of the century. On the face of things, these good intentions do not match the other developments last week in Moscow - not least, Reagan's belated conversion to the view that Gorbachev may be the best thing to have happened to the Soviet Union in 70 years, but also the ratification (delayed as well) of the INF treaty. Yet, in the long run, the Soviet Union's wish to join the now half-global economic system will be more important, not merely for Soviet citizens but for the rest of us.

This is why. Convertible currencies and GATT rules have been the principal driving forces of the remarkable expansion in the past several decades of world trade, whose annual volume has grown even faster than the domestic economy of Japan. That trend, in its quiet way, has done as much to change the world as any of the other momentous tendencies since the Second World War - the threat that nuclear weapons might be used, the threat of climatic change not excepted. What the growth of world trade has accomplished is a decisive (if needlessly slow) improvement in the economic division of labour and, as a consequence, the astonishing enrichment of the people of the industrialized world and a general realization of their interdependence. But the isolation of the Soviet Union and its neighbours from this system has meant that the division of labour has not been as effective as it might have been, that both halves of the world's economy (but the Soviet half especially) have been needlesly impoverished and that the economic disparities have engendered political rivalry and tension. That is the sense in which the new Soviet ambition may be more important even than the INF treaty.

\section{Ambition}

But is the ambition attainable? While the decision to seek to belong to the Western trading system is by no means the most breathtaking of the changes to have been brought about by Moscow in the past two years, it will be a monumental break with the past, during which Soviet spokesmen have diligently branded the West's trading arrangements as gigantic cartels. It will be easier to tell which way the wind is blowing after the party conference arranged in Moscow for the 27 June.

But there are also technical, economic and social obstacles to be overcome. Joining GATT will require that the Soviet Union should have gone a long way to rationalize its domestic economy, charging realistic prices for the goods its people buy. There will be endless popular protests if the universal subway fare is increased, but there will also be heart-searching among the party's old guard about the compatibility of such realism with the theoretical foundations of the Soviet state. Certainly it will need a remarkable conjuring trick to make it all happen in the two years the ministry of overseas economic affairs is talking of. Making the rouble convertible is an even greater task, requiring nothing less than making a substantial slice of Soviet industry competitive with that of the West. In the Soviet Union and elsewhere, people will be keeping their fingers crossed.

\section{Prizes}

Yet foreign trade will not be at the head of the agenda for the conference at the end of this month. Indeed, the ambition to join the rest of the world in trade is itself dependent on the outcome of more immediate decisions that will be needed - not merely the decentralization of the political system, but how to reorganize Soviet industry and to couple it more effectively to the huge but ineffectual research enterprise. But that will bring another prize for the West (not to mention the Soviet Union): a more fruitful relationship between two productive research communities separated from each other for far too long by external constraints. Those who marvel that the Englishman Humphry Davy should have been able to make an extended carriage ride in France at the height of the Napoleonic wars will not be alone in asking what the benefits of genuinely free exchange between the West and the Soviet Union would bring. Last week's summiteers offered general encouragement, but the world is waiting to see the colour of their money.

To some extent, the issue of free exchange is clouded by the separate issue of those who wish to leave the Soviet Union, but who are still denied exit visas. This was predictably one of the contentious issues at least week's summit meeting. But those in the West who champion the cause of the refusniks (many of whom are denied jobs as well as visas and many of whom are scientists) may, for all kinds of humanitarian reasons, be flogging last decade's horse. If indeed the social upheaval under way in the Soviet Union turns out to be as profound as promised, may it not be that the interests of refusniks would be better served by effective restraints of racial and other prejudice than by exit visas, especially at such a time?

Much the same is true of the failure last week to reach an understanding on the promised treaty to reduce superpower strategic missiles by a half. Already (see Nature 333, 284; 1988) there are good grounds for believing that a fully verifiable treaty will be too complicated to administer.

The fact that the two foreign ministers in Moscow last week found themselves signing (perhaps only for cosmetic purposes) an agreement to regulate the carrying capacity of bomber aircraft for cruise missiles is a sign of how the details of the proposed treaty are in danger of getting out of hand. The process should in any case be simplified if the next US administration turns its back on the Strategic Defense Initiative (SDI), or merely lets it wither away. (Mr Michael Dukakis, likely to have been confirmed this week as the probable Democratic candidate for president, calls SDI a "fraud"; Mr George Bush, his almost certain opponent, is lukewarm about this as about most things.) Why not give the small armies of negotiators something more tangible into which to sink their teeth in the coming election months? 